\title{
Model Penerapan Model Pembelajaran Kooperatif Tipe GI (Group Investigation) Untuk Meningkatkan Hasil Belajar IPS/Sejarah Siswa Kelas IXG SMP Negeri 3 Semarapura
}

\section{Ni Ketut Sukasni ${ }^{1 *}$}

${ }^{1}$ SMP Negeri 3 Semarapura, Bali

\section{A R T I C L E I N F O \\ Article history: \\ Received 14 Desember 2019 \\ Accepted 23 Desember 2019 \\ Available online 31 \\ Desember 2019}

\section{Kata Kunci:} Kooperatip; GI; Hasil Belajar

Keywords:

Cooperative Learning Model; GI; Learning

Achievement
Model Pembelajaran

\begin{abstract}
A B S T R A K
Penelitian ini bertujuan untuk meningkatkan hasil belajar sejarah siswa kelas IXG SMP Negeri 3 Semarapura pada semester 1 tahun pelajaran 2018/2019. Jenis penelitian ini adalah penelitian tindakan kelas yang melibatkan subjek penelitian sebanyak 27 orang siswa kelas IXG SMP Negeri 3 Semarapura. Objek penelitian ini adalah hasil belajar siswa kelas IXG SMP Negeri 3 Semarapura pada semester 1 tahun pelajaran 2018/2019 dengan penerapan model pembelajaran kooperatif tipe GI. Penelitian tindakan kelas ini dilakukan dalam dua siklus dimana data hasil belajar siswa dikumpulkan dengan menggunakan tes hasil belajar. Data yang telah terkumpul selanjutnya dianalisis secara deskriptif. Hasil penelitian menunjukkan bahwa penerapan model pembelajaran kooperatif tipe GI dapat meningkatkan hasil belajar siswa, yaitu dari nilai rata-rata sebesar 7,19 dengan daya serap 71,9\% dan ketuntasan klaksikal 70,4\% pada siklus I menjadi 7,93 dengan daya serap 79,3\% dan ketuntasan klaksikal 100\% pada siklus II, keduanya berada pada kualifikasi baik.
\end{abstract}

\section{A B S T R A C T}

This research primarily aims to improve the achievement of learning history to the 9th year students of G SMP Negeri 3 Semarapura semester 1 in the year 2018/2019. This is a kind of class action research that involves 27 students of the 9th year of G SMP Negeri 3 Semarapura. The object of this research is the learning achievement of the 9th year students of G SMP Negeri 3 Semarapura semester 1 in the year 2018/2019 with the implementation of cooperative learning model GI (Group Investigation) type. This class action research is implemented into two cycles in which the students are learning achievement collected using a learning achievement test. The data which has been obtained then analyzed descriptively. The research achievement shows that the implementation of cooperative learning model on GI type can improve the students learning progress, as the following cycle I: the average is 7,19 the percentage of comprehending ability is 71,9\%, and classical achievement is $70,4 \%$ cycle II: the standard is 7,93 the percentage of grasping knowledge is $79,3 \%$. The classical result is $100 \%$, and both are in a suitable qualification.

Copyright (c) Universitas Pendidikan Ganesha. All rights reserved.

\footnotetext{
* Corresponding author.

E-mail addresses: ketut.sukasni@gmail.com
} 


\section{Pendahuluan}

Untuk mencapai tujuan pendidikan secara optimal, pengajar diharapkan memilih ataupun menerapkan model pembelajaran yang tepat dan sesuai dengan karakteristik materi yang diajarkan serta sesuai dengan kondisi peserta didik. Seperti pada kasus pembelajaran IPS sebagian berpusat pada kegiatan mendengar dan menghafal, belum mengarah pada kegiatan belajar aktif dan kreatif, artinya siswa membangun sendiri wawasannya, bekerja, dan berpikir seperti seorang ilmuan (Khafid, 2019). Model pembelajaran yang dianggap tepat dan sesuai dengan karakteristik materi yang diajarkan serta sesuai dengan kondisi peserta didik adalah belajar dalam suatu kelompok-kelompok kecil yang biasa disebut dengan model pembelajaran kooperatif (Wahyuni, 2018). Dengan mempelajari, mendiskusikan, menemukan solusi, dan menghayati sendiri konsep-konsep penting yang terkandung dalam materi ajar, diharapkan dapat meningkatkan pemahaman siswa, hasil belajar, dan menumbuhkan rasa percaya diri siswa (Khoirunisyah, Purwanti, \& Yanuarita, 2016).

Salah satu pendekatan yang layak diterapkan adalah pendekatan konstruktivisme model kooperatif, yang akan memberikan kesempatan kepada siswa untuk lebih aktif dan kreatif menemukan konsep baru berdasarkan pengalaman dan penemuannya sendiri (Wagiran, 2006). Pembelajaran kooperatif memiliki pengaruh positif dalam memperbaiki hubungan antar kelompok dan percaya diri siswa sehingga dapat menumbuhkan motivasi diri bagi siswa untuk mengulangi kegiatan tersebut (Slavin, 1995). Pembelajaran kooperatif juga memberi kesempatan kepada siswa untuk berinteraksi dengan siswa lainnya dalam memahami kebermaknaan isi pembelajaran dan bekerjasama secara aktif dalam menyelesaikan tugas (Ridhani, 2004).

Pembelajaran kooperatif merupakan sebuah kelompok strategi pengajaran yang melibatkan peserta didik bekerja secara berkolaborasi untuk mencapai tujuan bersama. Sedangkan menurut (Nasution, 2001), menyatakan pembelajaran kooperatif adalah suatu pembelajaran yang dibentuk dalam kelompok kecil dengan anggota kelompok bekerjasama mengoptimalkan dirinya dalam belajar untuk menyelesaikan tugas. Mengacu kedua pendapat di atas maka bisa disimpulkan bahwa pembelajaran kooperatif merupakan pembelajaran yang mampu melibatkan peserta didik secara kolaboratif dalam kelompok kecil, yang memberikan ruang dan kesempatan kepada peserta didik untuk berkomunikasi, berinteraksi dan belajar bersama-sama dengan latar belakang yang berbeda. Dengan belajar kooperatif, diharapkan peserta didik memiliki sikap solidaritas dan sportifitas yang tinggi untuk mencapai tujuan bersama.

Model pembelajaran kooperatif yang memberikan kesempatan kepada siswa untuk mengembangkan pola fikirnya secara optimal adalah kooperatif tipe group investigation (GI) (Naim, 2017). Model pembelajaran group investigation (GI) merupakan model pembelajaran kooperatif yang paling kompleks dan dikembangkan pertama kali oleh Herbert Thelen. Model group investigation (GI) secara utuh memiliki enam langkah pembelajaran (Slavin, 1995) yaitu: (1) grouping, (2) planning, (3) investigation, (4) organizing, (5) presenting, dan (6) evaluating. Sistem sosial yang dikembangkan adalah minimnya arahan guru, demokratis, guru dan siswa memiliki status yang sama yaitu menghadapi masalah, interaksi dilandasi oleh kesepakatan. Guru lebih berperan sebagai konselor, konsultan, dan sumber kritik yang konstruktif.

Berdasarkan uraian singkat di atas, sebagai peningkatan hasil belajar siswa maka peneliti mencoba menerapkan model pembelajaran kooperatif tipe group investigation (GI) di kelas IXG SMP Negeri 3 Semarapura. Sehingga peneliti memberi judul penelitian ini dengan "Penerapan Model Pembelajaran Kooperatif Tipe GI (group investigation) untuk Meningkatkan Hasil belajar IPS/Sejarah Siswa Kelas IXG SMP Negeri 3 Semarapura".

Adapun tujuan yang ingin dicapai dalam penelitian tindakan ini adalah untuk Meningkatkan hasil belajar sejarah Siswa Kelas IXG SMP Negeri 3 Semarapura melalui Penerapan Model Pembelajaran Kooperatif tipe GI. Hasil penelitian ini dapat memberikan manfaat untuk pengembangan hasil pembelajaran Sejarah Hasil belajar adalah penguasaan seseorang terhadap pengetahuan atau ketrampilan tertentu dalam suatu mata pelajaran. Dalam hal ini ketrampilan yang dikuasai dapat diterapkan di lingkungan sekolah maupun masyarakat secara langsung (Nasution, 2001). Sedangkan Nawawi (2004) menyatakan bahwa hasil belajar 
(achievement) dapat diartikan sebagai tingkat keberhasilan murid dalam mempelajari materi yang dinyatakan dalam bentuk skor yang diperoleh dari hasil tes mengenai sejumlah materi tertentu. Jadi, hasil belajar adalah kemampuan yang dapat berupa kognitif, afektif, dan psikomotor yang dapat diketahui dari penampilan maupun kecenderungan perilaku, yang diperoleh setelah melakukan kegiatan belajar (Naim, 2017).

\section{Metode}

Penelitian ini merupakan penelitian tindakan kelas (PTK) yang secara umum bertujuan untuk meningkatkan dan memperbaiki kualitas proses pembelajaran di kelas yang bermuara pada peningkatan hasil belajar siswa. Penelitian ini dilaksanakan pada satu kelas yang mempunyai masalah pembelajaran.

Subjek penelitian ini adalah semua siswa kelas IXG SMP Negeri 3 Semarapura yang berjumlah 27 orang dimana terdiri dari 10 orang laki-laki dan 17 orang perempuan. Alasan pengambilan subjek penelitian ini karena kecendrungan guru mempertahankan penggunaan metode konvensional dalam pembelajaran di kelas, kurangnya keakraban siswa di kelas, ratarata hasil belajar siswa yang masih rendah. Objek penelitian ini adalah: 1) hasil belajar siswa kelas IXG SMP Negeri 3 Semarapura dengan penerapan model pembelajaran kooperatif tipe GI.

Prosedur penelitian ini dibagi dalam dua siklus dengan masing-masing siklus terdiri dari empat tahapan yaitu: (1) perencanaan, (2) tindakan, (3) observasi/evaluasi, dan (4) refleksi. Dalam kedua siklus tersebut dilaksanakan pembelajaran dan penilaian, dimana rincian perlakuan yang diberikan pada masing-masing siklus dikembangkan melalui pembelajaran dengan model group investigation (GI).

Teknik pengumpulan data yang digunakan dalam penelitian adalah dengan memberikan tes hasil belajar yang dilaksanakan setiap akhir siklus. Tes hasil belajar siswa (ulangan harian) yang diberikan pada setiap akhir siklus adalah berupa tes pilihan ganda dengan ketentuan jika jawaban benar diberi skor 1 dan jawaban salah diberi skor 0 .

Tes hasil belajar berupa tes yang dijawab oleh siswa sebagai responden. Tes hasil belajar dilakukan pada tiap akhir siklus, dan tes hasil belajar digunakan untuk menjaring penguasaan terhadap SK (Standar Kompetensi). Tes hasil belajar dilakukan untuk mengetahui hasil belajar siswa dengan penerapan model pembelajaran kooperatif tipe GI.

Hasil belajar siswa dianalisis secara deskriptif, yaitu dengan menentukan nilai hasil belajar siswa yang diperoleh melalui tes. Setelah diperoleh skor hasil belajar siswa, selanjutnya dicari skor rata-rata hasil belajar siswa $(\bar{X})$ dengan rumus:

$$
\begin{array}{ll}
\bar{X}=\frac{\sum X}{N} & \\
\sum X \quad=\text { jumlah skor kognitif siswa } \\
\mathrm{N} \quad=\text { banyak siswa }
\end{array}
$$

Skor rata-rata hasil belajar siswa yang diperoleh dari perhitungan dibandingkan dengan skor penggolongan yang telah ditetapkan. Penelitian tindakan kelas ini dikatakan berhasil apabila skor hasil belajar siswa minimal berada pada kualifikasi baik. Ketuntasan aspek hasil belajar siswa dapat di tentukan dengan menggunakan daya serap siswa (DSS) dan ketuntasan klasikal (KK).

$$
\begin{aligned}
& \text { DSS }=\frac{\text { Jumlah total skor yang dicapai siswa }}{\text { Jumlah total skormaksimum }} \times 100 \% \\
& \mathrm{KK}=\frac{\text { Banyak siswa yang tuntas }}{\text { Banyak siswa yang ikut tes }} \times 100 \%
\end{aligned}
$$


Siswa dikatakan berhasil atau tuntas jika DSS $\geq 70 \%$ dan satu kelas di katakan tuntas jika KK $\geq$ 75\%. Hal ini sesuai dengan kriteria yang ditetapkan oleh SMP Negeri 3 Semarapura .

Sumber data dalam Penelitian Tindakan ini terdiri dari beberapa sumber yakni: (1) siswa, untuk mendapatkan data tentang hasil belajar, (2) guru, untuk melihat tingkat keberhasilan implementasi pembelajaran dengan model pembelajaran kooperatif tipe GI dan hasil belajar siswa dalam proses belajar mengajar, (3) observer, sebagai sumber data untuk melihat implementasi penelitian tindakan dari sisi guru dan siswa.

Dalam pengujian hipotesis tindakan, nilai yang digunakan hanya nilai rata-rata siswa di akhir tiap siklus. Ini diakibatkan karena refleksi proses pembelajaran dilaksanakan di akhir tiap siklus. Hipotesis yang diajukan dan diuji dalam penelitian tindakan ini yaitu, Pengujian peningkatan hasil belajar siswa dilakukan berdasarkan perbandingan nilai rata-rata ulangan siswa di akhir siklus I dengan nilai rata-rata ulangan siswa di akhir siklus II. Persentase perbandingan tersebut, selanjutnya digunakan untuk menyimpulkan kuantitas peningkatan pemahaman konsep siswa. Semua analisis data dilakukan secara deskriptif dengan menggunakan bantuan program Microsoft Excel for Windows.

\section{Hasil dan Pembahasan}

Dalam proses pembelajaran, pelaksanaan kegiatan pembelajaran disesuaikan dengan langkah-langkah model pembelajaran group investigation (GI). Berikut ini akan dipaparkan lebih lanjut tentang deskripsi proses pembelajaran dan hasil penelitian pada siklus I dan siklus II.

Proses pembelajaran pada siklus I terdiri atas 3 pertemuan, yaitu mencakup bahasan Usaha Mempertahankan Kemerdekaan Indonesia yaitu pertemuan pertama dilakukan diskusi kelompok dan guru hanya sebagai fasilitator, pertemuan 2 dilakukan presentasi tentang hasil diskusi dari pertemuan pertama yaitu tentang Usaha Mempertahankan Kemerdekaan Indonesia dan pertemuan ketiga dilakukan tes hasil belajar siswa.

Pada pertemuan pertama, siswa belajar tentang pokok bahasan Usaha Mempertahankan Kemerdekaan Indonesia yang mencakup kembalinya Belanda ke Indonesia, perjuangan militer mempertahankan kemerdekaan Indonesia, perjuangan diplomasi mempertahankan kemerdekaan Indonesia.

Pertemuan kedua siswa diajak peneliti untuk membahas materi yang telah didiskusikan pada pertemuan sebelumnya. Dimana pada pertemuan ini merupakan tahap presentasi, peneliti mempersilahkan siswa untuk mempresentasikan hasil diskusi kelompoknya didepan kelas secara bergiliran. Pada tahap evaluasi, siswa yang telah selesai melakukan presentasi dipersilahkan untuk kembali ketempat duduknya masing-masing. Peneliti kemudian mengevaluasi pemahaman siswa dengan mengajukan beberapa pertanyaan. Berdasarkan pertanyaan yang diberikan, siswa sudah mau memberikan tanggapan walaupun masih salah/kurang. Siswa diminta untuk mengerjakan soal-soal yang terdapat di dalam buku LKS, untuk mengetahui seberapa jauh pemahaman siswa terhadap materi yang telah dibelajarkan.

Pada pertemuan ketiga peneliti melaksanakan tes hasil belajar atau ulangan harian yang terdiri dari 10 soal obyektif. Sistem ulangan harian ini adalah close book dan sanksi bagi yang ketahuan menyontek atau bekerja sama adalah nilainya dianggap nol dan tidak diijinkan kembali untuk melanjutkan menjawab pertanyaan. Alokasi waktu tes adalah 80 menit. Data hasil belajar siswa yang diperoleh dari hasil evaluasi Siklus I dapat ditunjukkan seperti pada Tabel 3.1.

Tabel 3.1

Data Hasil Belajar Siswa Pada Siklus I Dalam Pembelajaran IPS/Sejarah dengan Penerapan Model Pembelajaran Kooperatif Tipe GI

\begin{tabular}{|c|c|c|c|c|}
\hline No & Skor & Kualifikasi & Frekuensi & Presentase \\
\hline 1 & $10>X \geq 8,5$ & Sangat baik & 4 & $14,8 \%$ \\
\hline 2 & $8,5>X \geq 7,0$ & Baik & 15 & $55,6 \%$ \\
\hline 3 & $7,0>X \geq 5,5$ & Cukup baik & 5 & $18,5 \%$ \\
\hline 4 & $5,5>X \geq 4,0$ & Kurang baik & 2 & $7,4 \%$ \\
\hline 5 & $4,0>X \geq 0,0$ & Sangat kurang baik & 1 & $3,7 \%$ \\
\hline
\end{tabular}


Berdasarkan tabel diatas hasil belajar siswa pada siklus I belum mencapai hasil yang maksimal. Hal ini terlihat dari frekuensi ketuntasan siswa dimana terdapat 8 orang siswa yang belum tuntas dengan kualifikasi sangat kurang baik 3,7\%, kualifikasi kurang baik 7,4\% dan kualifikasi cukup baik 18,5\% . Sementara 19 orang siswa sudah tuntas dengan presentase ketuntasan 14,8 \% dengan kualifikasi sangat baik, 55,6\% dengan kualifikasi baik. Secara klasikal hasil belajar siswa kelas IXG SMP Negeri 3 Semarapura pada siklus I mencapai rata-rata 7,19 dengan daya serap 71,9\%, dan ketuntasan klaksikal 70,4 \%. Hal ini menunjukkan bahwa kelas IXG belum tuntas secara klasikal, dimana ini terlihat dari ketuntasan klasikal masih kurang dari $75 \%$ yang mana merupakan kriteria keberhasilan pembelajaran secara menyeluruh dalam suatu kelas.

Peneliti selanjutnya melakukan refleksi secara umum tentang proses pembelajaran selama siklus I. Hasil refleksi tersebut akan dijadikan sebagai acuan untuk pelaksanaan tindakan pada proses pembelajaran siklus II. Secara umum, siswa tampak antusias dalam melakukan diskusi kelompok. Walaupun ada beberapa orang siswa yang kelihatannya kurang aktif dan bermain-main dengan temannya. Proses pembelajaran pada siklus I secara umum berlangsung baik.

Belum tuntasnya pembelajaran pada siklus I disebabkan karena dalam proses pembelajaran masih terdapat permasalahaan yang terungkap dari kegiatan observasi yang dilakukan selama pelaksanaan tindakan siklus I. Selama pelaksanaan siklus I dengan penerapan model pembelajaran kooperatif tipe GI dapat diamati hal-hal berikut.

1) Pada pertemuan pertama, siswa belum mempersiapkan diri sebelum mengikuti pembelajaran, hal ini dapat dilihat ketika peneliti bertanya kebanyakan siswa terdiam dan ada beberapa siswa baru mulai membaca buku. Dari kelemahan ini peneliti berinisiatif menyuruh siswa untuk membaca terlebih dahulu materi pembelajaran yang akan dibahas sebelum pembelajaran dimulai.

2) Beberapa siswa terlihat bingung dan kurang teratur dalam mengerjakan LKS yang diberikan, hal ini terjadi karena siswa kurang memperhatikan arahan yang diberikan saat mengerjakan LKS.

3) Pada pertemuan kedua siswa belum mampu melakukan kegiatan presentasi kelompok secara maksimal, bahkan siswa masih bingung bagaiamana cara menyajikan laporan hasil diskusi.

4) Pada saat presentasi kelompok berlangsung, siswa belum mampu untuk melaksanakan diskusi atau mengungkapkan gagasannya dengan baik, hal ini terlihat dari kurang aktifnya bertanya siswa mengenai materi pembelajaran atau pemecahan masalah yang sedang didiskusikan.

Berdasarkan temuan dari kegiatan observasi yang dilakukan selama pelaksanaan tindakan 1, maka diadakan upaya untuk memperbaiki pelaksanaan tindakan berikutnya yaitu sebagai berikut.

1) Menugaskan siswa untuk membaca materi pembelajaran yang akan dibahas pada pertemuan selanjutnya. Hal ini dilakukan, agar siswa memiliki persiapan sebelum pembelajaran dimulai/dilakukan.

2) Mengarahkan siswa dengan mendekati tiap-tiap kelompok yang belum mengerti dan memberikan penekanan pada konsep yang harus diketahui dan dimengerti pada tiap tahapan dalam memecahkan masalah.

3) Peneliti merangsang siswa kelompok lain dengan memberikan nilai plus bagi siswa yang mampu memberikan masukan/tanggapan yang bermanfaat bagi hasil penyelidikan yang dilakukan oleh kelompok lain

Pelaksanaan tindakan pada siklus II disesuaikan dengan hasil refleksi kegiatan siklus I. Sesuai dengan jumlah sebaran materi, pembelajaran dikemas dalam rencana pembelajaran yang dalam penerapannya dibantu dengan penggunaan Uji Kompetensi 2( LKS 2 ).

Proses pembelajaran pada siklus II terdiri atas 3 pertemuan, yaitu mencakup bahasan

Perkembangan Politik dan Ekonomi Indonesia dan Pengakuan Kedaulatan yaitu pertemuan pertama dilakukan diskusi kelompok dan guru hanya sebagai fasilitator, pertemuan 2 dilakukan 
presentasi tentang hasil diskusi dari pertemuan pertama yaitu tentang Pergerakan Nasional dan pertemuan ketiga dilakukan tes hasil belajar siswa.

Kegiatan tes berlangsung lebih lancar dibandingkan dengan tes pada siklus I, tidak ada siswa yang terlihat nyontek, walaupun ada beberapa siswa yang mau mencoba tetapi karena peneliti berkeliling ruangan kelas, membuat seluruh siswa berusaha untuk menyelesaikan tes secara mandiri agar tidak terkena sanksi yang telah disepakati bersama. Data hasil belajar siswa yang diperoleh dari hasil evaluasi Siklus II disajikan pada tabel 3.2 berikut.

\section{Tabel 3.2}

Data Hasil Belajar Siswa Pada Siklus II Dalam Pembelajaran IPS/Sejarah dengan Penerapan Model Pembelajaran Kooperatif Tipe GI

\begin{tabular}{|c|c|c|c|c|}
\hline No & Skor & Kualifikasi & Frekuensi & Presentase \\
\hline 1 & $10>X \geq 8,5$ & Sangat baik & 5 & $18,5 \%$ \\
\hline 2 & $8,5>X \geq 7,0$ & Baik & 22 & $81,5 \%$ \\
\hline 3 & $7,0>X \geq 5,5$ & Cukup baik & 0 & $0 \%$ \\
\hline 4 & $5,5>X \geq 4,0$ & Kurang baik & 0 & $0 \%$ \\
\hline 5 & $4,0>X \geq 0,0$ & Sangat kurang baik & 0 & $0 \%$ \\
\hline
\end{tabular}

Berdasarkan tabel diatas hasil belajar siswa pada siklus II sudah mencapai hasil yang maksimal. Hal ini terlihat dari rata-rata mencapai 7,93 dengan daya serap $79,3 \%$ dan ketuntasan klaksikal sudah mencapai $100 \%$ atau semua siswa kelas IXG sudah tuntas pada pokok bahasan Perkembangan Politik dan Ekonomi Indonesia.

Setelah diadakan upaya perbaikan pada siklus II, hasil belajar siswa sudah mengalami peningkatan. Hal ini ditunjukkan dengan persentase ketuntasan secara klaksikal sudah mencapai $100 \%$. Selama pelaksanaan siklus II dengan penerapan model pembelajaran kooperatif Tipe GI dapat diamati hal-hal berikut.

1) Secara umum, pada awal pelaksaraan siklus II, siswa sudah mengerti jalannya pembelajaran dengan tuntunan LKS dan siswa sudah mulai aktif dalam penyelidikan/pencarian informasi untuk memecahkan masalah yang diberikan serta siswa sangat sedikit memerlukan arahan dari guru untuk memecahkan masalah. Guru hanya sebagai fasilitator dan mediator pada kegiatan diskusi pembelajaran.

2) Semua anggota kelompok sudah merniliki rasa tanggung jawab terhadap kelompoknya, hal ini terlihat dari kesiapan siswa dalam mempresentasikan basil diskusinya.

3) Setelah guru memfasilitasi, siswa sudah mampu melaksanakan presentasi kelompok dengan baik. Hal ini terlihat dari banyaknya siswa kelompok lain yang terlibat aktif dalam presentasi untuk memberikan pertanyaan serta masukan kepada penyaji. Sehingga jalannya persentasi berlangsung dengan baik.

Hasil dari refleksi ini digunakan sebagai dasar untuk menyusun rekomendasi untuk saran tindakan bagi guru mata pelajaran sejarah yang ingin mcnerapkan strategi pemecahan masalah dengan setting kooperatif group investigation (GI). Adapun refleksi yang dilakukan adalah sebagai berikut.

1) Dengan tetap memberi motivasi pada siswa, secara umum siswa sudah mampu melaksanakan penyelidikan sesuai dengan petunjuk yang diberikan sehingga siswa memiliki pengetahuan untuk memecahkan masalah.

2) Dengan mengarahkan pada tujuan pembelajaran yang ingin dicapai pada saat presentasi kelompok, siswa sudah mampu membuat kesimpulan ataupun rangkuman sesuai dengan indikator hasil belajar yang telah ditetapkan.

3) Dengan menyusun LKS secara lebih terinci, maka siswa sudah mampu melaksanakan penyelidikan dengan lancar tanpa banyak bertanya.

4) Dengan tetap memberikan motivasi kepada siswa, secara umum siswa dalam kelompoknya mau melakukan penyelidikan dengan serius dan tidak mengandalkan salah satu temannya yang dianggap lebih pintar. Mereka merasa penyelidikan yang dilakukan akan bermanfaat bagi dirinya. 
5) Dengan meningkatkan fungsi guru sebagai fasilitator dan tetap mengarahkan jalannya presentasi kelompok hasil penyelidikan, secara umum siswa terlibat aktif dalam kegiatan presentasi. Hal ini dapat dilihat dari banyaknya siswa yang memberikan tanggapan kepada penyaji saat presentasi kelompok berlangsung.

Berdasarkan hasil penelitian yang telah dilaksanakan selama dua siklus menunjukkan terjadinya peningkatan hasil belajar siswa dengan penerapan model pembelajaran kooperatip tipe GI. Berdasarkan analisis nilai rata-rata hasil belajar pada siklus I, menunjukkan bahwa nilai rata-rata sebesar 7,19, daya serap siswa 71,9\% dengan standar deviasi 1,41 dan ketuntasan klasikal 70,4\%. Pada siklus I dari jumlah siswa sebanyak 27 orang diperoleh jumlah siswa yang tuntas 19 orang dan yang tidak tuntas 8 orang, sehingga ketuntasan klasikal yang dicapai sebesar 70,4\%. Sementara penelitian dikatakan berhasil jika siswa tuntas secara individu dengan perolehan nilai hasil belajar minimal mencapai angka 7,0 dan ketuntasan klasikal minimal mencapai 75\%. Belum tercapainya kriteria keberhasilan pemahaman konsep siswa seperti yang telah ditetapkan, disebabkan oleh beberapa temuan kendala-kendala dan permasalahan yang terjadi selama tindakan siklus I seperti yang telah dipaparkan pada hasil refleksi siklus I sebelumnya.

Untuk mengatasi kendala-kendala dan permasalahan yang ditemui tersebut, dilakukan tindakan perbaikan seperti yang telah dipaparkan pada hasil refleksi siklus I. Perbaikan tindakan yang dilakukan untuk memperbaiki pencapaian hasil belajar siswa pada siklus II, maka dilakukan upaya-upaya sebagai berikut: memberikan tugas pada siswa untuk membaca materi pembelajaran yang akan dibelajarkan sehingga siswa memiliki persiapan sebelum pembelajaran di kelas berlangsung, memberikan bimbingan yang lebih intensif pada siswa saat memecahkan masalah, memberikan motivasi pada siswa dengan mengaitkan materi pembelajaran dengan dunia nyata siswa, memancing siswa untuk mau bertanya dan berdiskusi mengenai masalah/materi pembelajaran yang belum dimengerti sehingga siswa yang lain dapat berdiskusi dan mengungkapkan gagasannya. Setelah dilakukan upaya perbaikan pada siklus II, maka nilai rata-rata hasil belajar siswa untuk di akhir siklus mengalami peningkatan.

Berdasarkan analisis data nilai rata-rata hasil belajar pada siklus II, menunjukkan bahwa nilai rata-rata sebesar 7,93, daya serap siswa 79,3\% dengan standar deviasi 0,78 dan ketuntasan klasikal mencapai 100\%. Baik siklus I ke siklus II terjadi peningkatan hasil belajar siswa sebesar 7,4\%. Ini berarti dengan penerapan model pembelajaran kooperatif tipe GI dapat meningkatkan hasil belajar siswa dalam pembelajaran sejarah.

Pendidikan mempunyai posisi penting dalam rangka peningkatan kualitas sumber daya manusia. Posisi yang penting tersebut dapat tercapai apabila pendidikan yang dilaksanakan mempunyai kualitas yang memadai. Kualitas pendidikan dapat diketahui dari dua hal, yaitu: kualitas proses dan produk. Suatu pendidikan dikatakan berkualitas proses apabila proses belajar mengajar (PBM) dapat berlangsung secara efektif dan peserta didik mengalami proses pembelajaran yang bermakna. Pendidikan disebut berkualitas produk apabila peserta didik menunjukkan tingkat penguasaan yang tinggi terhadap tugas-tugas belajar sesuai dengan sasaran dan tujuan pendidikan. Pendidikan dikatakan berkualitas apabila terjadi penyelenggaraan pembelajaran yang aktif, efektif, inovatif, kreatif dan menyenangkan dengan melibatkan semua komponen-komponen pendidikan, seperti mencakup tujuan pengajaran, guru dan peserta didik, bahan pelajaran, strategi atau metode belajar mengajar, alat dan sumber pelajaran serta evaluasi. Komponen-komponen tersebut dilibatkan secara langsung tanpa menonjolkan salah satu komponen saja, akan tetapi komponen tersebut diberdayakan secara bersama-sama (Putrawan, 2019).

Nasution (2001) menjelaskan bahwa upaya meningkatkan kualitas pendidikan terus menerus dilakukan dengan baik secara konvensional maupun inovatif. Hal tersebut lebih terfokus lagi setelah diamanatkan bahwa tujuan pendidikan nasional adalah untuk meningkatkan mutu pendidikan pada setiap jenis dan jenjang pendidikan. Peningkatan mutu pendidikan pada awalnya diwujudkan melalui peningkatan mutu pembelajaran di kelas. Berkaitan dengan hal tersebut, guru sebagai tenaga pendidik profesional mempunyai peran sangat penting. 
Guru merupakan salah satu kunci sukses yang menentukan keberhasilan pendidikan, karena apapun tujuan dan putusan-putusan penting tentang pendidikan yang dibuat oleh para pembuat kebijakan sebenarnya dilaksanakan dalam situsasi pembelajaran di kelas. Dalam usaha meningkatkan kualitas pendidikan, salah satunya diperlukan suatu strategi dan metode pembelajaran yang tepat dan jitu. Selama ini guru masih mengalami berbagai kendala dalam menciptakan suasana belajar yang kondusif bagi peserta didik, sehingga guru mengalami kesulitan dalam menarik perhatian peserta didik dan mendorong partisipasi serta keaktifan peserta didik dalam proses belajar mengajar, yang berdampak pada kurang optimalnya prestasi belajar peserta didik. Salah satunya disebabkan penerapan metode pembelajaran yang kurang tepat.

Metode mengajar guru yang kurang tepat akan mempengaruhi peserta didik dalam belajar, yang bermuara pada hasil belajar yang kurang optimal. Untuk itulah guru harus mampu memiliki kepekaan serta kemampuan mengemas pembelajaran sehingga pembelajaran tidak terkesan kaku yang sekaligus mampu mengakomodir serta mengelola partisipasi dan peran peserta didik dalam proses pembelajaran. Untuk mengimbangi realita tersebut, maka guru sebagai agen perubahan harus memiliki ide, konsep dan inovasi dalam pembelajaran, terutama dari strategi pembelajaran yang diterapkan. Paradigma pembelajaran yang lama yang hanya mengembangkan kemampuan kognitif peserta didik saja, harus diubah menjadi paradigma pengajaran baru yang mampu mengembangkan kemampuan kognitif (pengetahuan), afektif (sikap) dan psikomotorik (keterampilan) pada diri peserta didik.

Hasil temuan penelitian ini sejalan dengan Sujaya (2005) yang berhasil membuktikan bahwa dengan menggunakan model pembelajaran group investigation (GI) dalam pembelajaran kontesktual dapat meningkatkan kompetensi dasar fisika siswa SMP Negeri 1 Singaraja. Disamping itu, menurut hasil penelitian Putrawan (2019) menemukan bahwa pembelajaran dengan pembelajaran kooperatif dapat mengembangkan kompetensi dasar siswa melalui kegiatan percobaan, komunikasi maupun penggunaan pengetahuan PPKn ketika siswa menyajikan suatu pernecahan masalah. Hal ini mengindikasikan bahwa penerapan model pembelajaran kooperatif efektif diterapkan dalam pembelajaran PPKn untuk meningkatkan hasil belajar siswa. Hal ini sejalan dengan penelitian (Arisinta, 2017) metode GI bisa meningkatkan kualitas pembelajaran sehingga anak-anak lebih menarik untuk belajar. Melalui pembelajaran kooperatif, guru diharapkan dapat mengelola kelas dengan lebih efektif. Selain guru, peserta didik juga diharapkan lebih bertanggung jawab terhadap tugasnya serta dapat menumbuhkan rasa saling ketergantungan antar teman sejawat di dalam kelompoknya. Sejalan dengan hasil penelitian ini, Setiawan, Maryani, \& Nandi (2018) menemukan bahwa peserta didik akan semakin antusias untuk meningkatkan hasil belajar karena setiap akhir pembelajaran guru memberikan penghargaan kepada kelompok yang mampu mencapai nilai yang paling baik. Pada penelitian lain, peserta didik mulai terbiasa untuk mengemukakan pendapat tanpa adanya rasa malu karena semua peserta didik akan berlomba-lomba untuk memperoleh hasil terbaik demi kemajuan kelompok (Lestari, Setiawan, \& Puspitaningrum, 2018).

Temuan yang diperoleh mengenai hasil belajar siswa terhadap penerapan model pembelajaran kooperatif GI (group investigation), memiliki implikasi bahwa pembelajaran sejarah bermakna bagi siswa karena konsep yang diperolehnya digunakan untuk memecahkan masalah yang ada disekitar lingkungannya dan dapat menumbuhkan interaksi sosial dalam kelas sehingga siswa dapat berbagi ide atau pendapat untuk mencari solusi/pemecahan dari suatu masalah (Siregar \& Mara, 2016). Artinya pembelajaran tidak hanya dalam tatanan kognitif tetapi menjadi nilai yang sudah terinternalisasi dalam diri siswa (Matroji, 2016). Internalisasi ini akan menjadikan mata pelajaran IPS khususnya sejarah menjadi role model pengembangan dan penguatan karakter sebagai tujuan akhir pendidikan (Rulianto, 2018).

\section{Simpulan dan Saran}

Berdasarkan hasil penelitian dan pembahasan yang telah diuraikan pada bab sebelumnya, maka dapat disimpulkan bahwa, penerapan model pembelajaran kooperatif tipe group investigation (GI) dapat meningkatkan hasil belajar siswa kelas IXG SMP Negeri 3 Semarapura. Hal ini dapat dilihat dari nilai rata-rata hasil belajar siswa pada siklus I sebesar 7,19 dengan daya serap 
71,9\% dan ketuntasan klasikal 70,4\% sedangkan pada siklus II meningkat menjadi 7,93 dengan daya serap 79,3\% dan ketuntasan klasikal 100\%. Secara kuantitas terjadi peningkatan hasil belajar sejarah siswa ( 7,93 - 7,19) 0,74 atau siswa sebesar 7,4\%. Dalam kenyataannya masih banyak dijumpai permasalahan dalam proses pembelajaran, diantaranya kurangnya perhatian peserta didik dalam pembelajaran yang terlihat dari maraknya peserta didik yang ribut dalam pembelajaran, minimnya sumber belajar peserta didik yang berakibat sulitnya mendapat informasi yang dibutuhkan, komunikasi bersifat satu arah karena dominasi guru dalam pembelajaran terlalu tinggi, penggunaan metode yang monoton sehingga peserta didik kurang diberi ruang untuk berpartisipasi secara optimal dalam pembelajaran. Semua realita diatas akhirnya bermuara dan berdampak pada rendahnya hasil belajar peserta didik.

Penerapan model pembelajaran kooperatif tipe group investigation (GI) dapat digunakan sebagai salah satu alternatif model pembelajaran dalam upaya meningkatkan hasil belajar siswa, lebih mengarahkan siswa dalam melakukan diskusi secara optimal. Oleh karena itu guru sebaiknya memperhatikan beberapa hal seperti menyiapkan diri sebagai fasilitator dan mediator yang baik bagi siswa dalam belajar di kelas maupun diluar kelas.Untuk itu, kepada guru sejarah pada umumnya, disarankan untuk mencoba menerapkan model pembelajaran kooperatip tipe group investigation (GI) pada pokok bahasan lain.

\section{Daftar Rujukan}

Arisinta, R. (2017). Pengembangan Group Investigation Dengan Permainan "Aku Seorang Detektif" Kelas IV SD Muhammadiyah 1 Malang. Jurnal Pemikiran Dan Pengembangan SD, 5(2), 732-742.

Khafid, S. (2019). Pengembangan Desain Pembelajaran Geografi dengan Pendekatan Konstruktivistik. Jurnal Ilmiah Ilmu Sosial, 5(1), 1-12.

Khoirunisyah, S., Purwanti, E., \& Yanuarita, P. (2016). Keefektifan Model Pembelajaran Group Investigation Terhadap Hasil Belajar IPS. Jurnal Kreatif, 7(1), 73-80.

Lestari, P., Setiawan, A., \& Puspitaningrum, A. (2018). Urgensi Habituasi Nilai Karakter Kemandirian Dan Tanggung Jawab Peserta Didik Sekolah Menengah Keguruan. Jurnal Ilmiah Ilmu Sosial, 4(2), 114-119.

Matroji. (2016). Penerapan Model Group Investigation Untuk Meningkatkan Hasil Belajar Siswa Dalam Pembelajaran Sejarah Materi Pengaruh Sejarah Dunia Terhadap Sejarah Bangsa Indonesia Abad 18-20. Pedagogia, 14(2), 356-362.

Naim, M. (2017). Upaya Meningkatkan Aktivitas Dan Hasil Belajar Penerapan Melalui Model Pembelajaran Kooperatif Tipe Group Investigation Pada Mata Pelajaran Sejarah. Jurnal Pendidikan Dan Humaniora, 55(1), 75-81.

Nasution. (2001). Berbagai Pendekatan dalam Proses Belajar dan Mengajar. Jakarta: Bumi Aksara.

Nawawi. (2004). Contextual Approach In Teaching And Learning Languages. Jurnal Ilmu Pendidikan, 16, 1438-1445.

Putrawan, N. E. (2019). Peningkatan Hasil Belajar Kognitif PPKn Siswa SMP Melalui Model Pembelajaran Kooperatif Tipe STAD. Jurnal Ilmiah Ilmu Sosial, 5(1), 13-22.

Ridhani, A. A. (2004). Pembelajaran Interpretatif Dengan Pendekatan Cooperative Learning Di Sekolah Dasar. Jurnal Ilmu Pendidikan, 11(1), 71-80.

Rulianto, F. H. (2018). Pendidikan Sejarah Sebagai Penguat Pendidikan Karakter. Jurnal Ilmiah Ilmu Sosial, 4(2), 127-134.

Setiawan, U., Maryani, E., \& Nandi. (2018). Pedagogical Content Knowledge (PCK) Guru Geografi SMA. Jurnal Ilmiah Ilmu Sosial, 4(1), 12-21.

Siregar, E., \& Mara, B. M. (2016). Pengaruh Model Pembelajaran Kooperatif Tipe Group Investigation (GI) Terhadap Pengetahuan Konseptual Siswa SMA Muhammadiyah 2 Medan T.P. 2015/2016. Jurnal INVAFI, 4(4), 1-10.

Slavin, R. E. (1995). Cooperatif Learning: 2nd Ed. Boston: Allyn and Bacon.

Sujaya. (2005). Penerapan Pendekatan Kontekstual Dengan Seting Kooperatif Tife Group Investigation Sebagai Upaya Meningkatkan Kompetensi Dasar Dalam Pembelajaran Energi Dan Usaha Pada Siswa Kelas IA2 SMP Negeri I Singaraja. Universitas Pendidikan Ganesha. 
Wagiran. (2006). Meningkatkan Keaktifan Mahasiswa Dan Reduksi Miskonsepsi Melalui Pembelajaran Konstruktivistik Model Kooperatif Berbantuan Modul. Jurnal Ilmu Pendidikan, 13(1), 25-32.

Wahyuni, N. L. P. W. (2018). Pengaruh Model Pembelajaran Kooperatif Tipe Group Investigation Berbantuan Asesmen Kinerja Terhadap Keterampilan Porses Sains. International Journal of Elementery Education, 2(3), 202-210. 